\title{
THE IMPACT OF THE COVID-19 PANDEMIC
}

\section{ON DMOS' PERCEPTION OF} SUSTAINABILITY IN DESTINATIONS:

\section{Jorge Rivera García}

Universitat Oberta de Catalunya (UOC) Barcelona, España

iD) 0000-0003-1868-647X

>1 iriveraga@uoc.edu

\section{A RESEARCH NOTE}

Ricardo Pastor Ruiz

Universidad de Deusto

Bilbao, España

D. 0000-0002-9302-7792

ricardo.pastor@deusto.es

\section{ABSTRACT}

Destination marketing and/or management organisations (DMOs) must manage crises that affect the image of the tourism destination. The use of communication in these scenarios is crucial. Recent studies suggest that, following the COVID-19 crisis, the demand for responsible tourism products should increase, leading to a more sustainable tourism. A study to examine the role of DMOs in responsible tourism during this crisis is underway to find out how the destination positioning is perceived in the current tourism context and what developments in DMOs marketing strategy on sustainable tourism are taking place as a consequence of the crisis impact.

\section{KEYWORDS}

Covid-19 $>$ crisis $>$ destination marketing organization $>$ stakeholder involvement $>$ sustainable tourism.

THE IMPACT OF THE COVID-19 PANDEMIC ON DMOS' PERCEPTION OF SUSTAINABILITY IN DESTINATIONS:

A RESEARCH NOTE

\section{Autores:}

Jorge Rivera García \& Ricardo

Pastor Ruiz
Ayana Revista de Investigación en Turismo | Año 1 I NNo2 Junio 2021 - Noviembre 2021

ISSN 2718-6717

Entidad editora Instituto de Investigaciones en Turismo, Facultad de Ciencias Económicas (Universidad Nacional de La Plata) La Plata I Buenos Aires I Argentina http://revistas.un/p.edu.ar/ayana 
EL IMPACTO DE LA PANDEMIA DEL COVID-19 EN LA PERCEPCIÓN DE LOS DMOS SOBRE LA SOSTENIBILIDAD EN LOS DESTINOS: UNA NOTA DE INVESTIGACIÓN

\section{RESUMEN}

Las organizaciones de marketing y/o gestión de destinos (DMOs) deben gestionar las crisis que afectan a la imagen del destino turístico, y el uso de la comunicación en estos escenarios es crucial. Estudios recientes sugieren que, tras la crisis de COVID-19, la demanda de productos turísticos responsables debería aumentar, dando lugar a un turismo más sostenible. Se está llevando a cabo una investigación para examinar el papel de los DMOs en el turismo responsable durante la crisis actual, con el fin de conocer cómo perciben el posicionamiento del destino en el contexto turístico actual y qué novedades, como consecuencia del impacto de la crisis, se están produciendo en su estrategia de marketing sobre el turismo sostenible.

\section{PALABRAS CLAVE}

Covid-19 crisis $>$ organización de marketing de destinos $>$ participación de las partes interesadas $>$ turismo sostenible.

\section{O IMPACTO DA PANDEMIA DA COVID-19 NA PERCEPÇÃO DOS DMOS SOBRE A SUSTENTABILIDADE NOS DESTINOS: UMA NOTA DE PESQUISA}

\section{RESUMO}

As organizações de marketing e/ou gestão de destinos (DMOs) devem gerenciar crises que afetam a imagem do destino turístico, e o uso da comunicação nestes cenários é crucial. Estudos recentes sugerem que, após a crise da Covid-19, a demanda por produtos turísticos responsáveis deve aumentar, levando a um turismo mais sustentável. Estão sendo realizadas pesquisas para examinar o papel dos $\mathrm{DMOs}$ no turismo responsável durante a crise atual, a fim de descobrir como eles percebem o posicionamento do destino no contexto turístico atual e quais desenvolvimentos, como consequência (sem trema, novo acordo ortográfico) do impacto da crise, estão ocorrendo em sua estratégia de marketing no turismo sustentável.

\section{PALAVRAS CHAVE}

Covid-19 > crise $>$ organização de marketing de destino participação $>$ atuação das partes interessadas $>$ turismo sustentável. 


\section{Introduction}

The COVID-19 crisis has had a significant impact on global activity, leading to a global economic recession (Bakar \& Rosbi, 2020). Travel restrictions have immediately affected national economies, and international tourism has declined sharply (Gössling et al., 2020). It is understood that, before we return to our previous normality or to a "new normality", there will be a phase of coexistence with the virus, in which travel attitudes and behaviour will be dramatically modified (Rivera García \& Pastor Ruiz, 2020). In addition, the pandemic effects appear to encourage the public to engage in activities in natural settings and on an individual basis due to the risk of infection through contact and crowding (García et al., 2020). Some of these new characteristics are entirely in line with the better-known characteristics of sustainable tourism and ecotourism (Rivera García \& Pastor Ruiz, 2020).

Crises are perceived as an opportunity to critically rethink the growth trajectory of tourism (Gössling et al., 2020). In seeking to return to the normal trajectory or to reach a new one, Blackman and Ritchie (2008) argue that some leaders need to emerge from among the different stakeholders working in the destination or with other organisations. A destination marketing organisation (DMO) can be defined as the entity responsible for marketing an identifiable destination (Wang, 2011). The communication addressed by DMOs to destination stakeholders plays a central role in attracting attention and resources for sustainable destination development and disseminating the efforts made to become a sustainable territory (d'Angella \& de Carlo, 2016). Among the four levels of stakeholder involvement in the destination management proposed by Morgan et al. (2012), the degree of involvement strongly depends on primary stakeholders, who are seen as key decision-makers in the branding process. These primary stakeholders include DMOs together with other governmental agents (Rivera García \& Pastor Ruiz, in press). It is imperative that DMOs use legislative and management tools during the planning and marketing of destinations to ensure that the benefits of tourism activity are shared equitably among all stakeholders and that sustainable practices safeguard the regeneration of resources used for tourism production (Buhalis et al., 1995). Despite the unquestioned relevance of DMOs as major agents for the promotion of tourism in destinations, current evidence from the academic literature discussing their importance in the application of sustainable tourism models is scarce. Nonetheless, changes in the governance and financing of DMOs offer opportunities for introducing new models that go beyond traditional management and marketing (Naumov et al., 2020). Hence, a study is being carried out with the overall purpose of testing the hypothesis of whether a foreseeable increase in the demand for sustainable tourism products after the current crisis would in turn impact DMOs regular activity. This research note tries to provide the first evidence arising from that study.

The specific objectives include the analysis of whether such impact would be similar throughout the different regions of the world and the establishment of different profiles of the organisations in order to analyse their perception of sustainable tourism and the extent to which they are willing to invest in this field in the future. An additional objective is to test whether DMOs would consider this situation as a turning point in this field and whether they would internally set themselves up as leaders in communicating this type of product or reach the different stakeholders of the destination and the market.

In a first phase, the data was obtained from the 10th of August to the 15th of September 2020, through an 
online survey sent by email to national, regional and local DMOs of 50 European countries: 43 with their entire territory in Europe and 7 Eurasian. In a second phase, the survey is being extended to other countries in order to contrast continent-wide benchmarks.

Results

Based on the sample obtained (417 records) and considering the population size of 2073 DMOs to which the survey was sent, the margin of error (MOE) was 3,43\% with a $95 \%$ confidence interval (z-score 1,96$)$.

The representativeness level of each geographic area is shown in Table 1.

Table 1. Survey Representativeness

\begin{tabular}{|l|c|c|c|}
\hline EU REGION & Sample Size & Population Size & Sample Proportion \\
\hline CENTRAL & 65 & 289 & $22,49 \%$ \\
\hline EAST & 47 & 106 & $44,34 \%$ \\
\hline NORTH & 62 & 259 & $23,94 \%$ \\
\hline SOUTH & 173 & 1323 & $13,08 \%$ \\
\hline WEST & 70 & 96 & $72,92 \%$ \\
\hline Total & 417 & 2073 & $20,12 \%$ \\
\hline
\end{tabular}

Source: Authors

Table 2 classifies the DMOs profile by geographical area, office type and organisational model:

Table 2. Survey Respondent Profile

\begin{tabular}{|c|c|c|c|}
\hline \multirow{3}{*}{ Area } & & $\mathrm{n}=417$ & $\%$ \\
\cline { 2 - 4 } & Central Europe & 65 & $15,60 \%$ \\
\hline & Eastern Europe & 47 & $11,30 \%$ \\
\hline & Northern Europe & 62 & $14,90 \%$ \\
\cline { 2 - 4 } & Southern Europe & 173 & $41,50 \%$ \\
\hline & Western Europe & 70 & $16,80 \%$ \\
\hline Office type & NTOs & 16 & $3,80 \%$ \\
\hline & RTOs & 90 & $21,60 \%$ \\
\hline Org. Model & Lublic property & 328 & $78,70 \%$ \\
\hline & Private property & 16 & $3,80 \%$ \\
\hline & Mix Publ. \& Private & 73 & $17,50 \%$ \\
\hline
\end{tabular}


The respondents' opinion regarding tourism sustainability in their destination after the Covid-19 pandemic was measured. $86,3 \%$ of the respondents assigned a positive rating (from 6 to 10 ) to the idea that sustainability matters to DMOs as sale marketing, and an even higher proportion $(92,1 \%)$ assigned a positive rating to the vision that there exists a potential demand for sustainable tourism products that must be satisfied specially after the Covid-19 pandemic.

Table 3. Self-Definition Rating Regarding Tourism Sustainability in the Destination

\begin{tabular}{|c|c|c|c|c|c|c|c|c|c|c|}
\hline & \multicolumn{2}{|c|}{ It hardly define us } & \multirow[b]{2}{*}{$3(\%)$} & \multirow[b]{2}{*}{$4(\%)$} & \multicolumn{3}{|c|}{ It define us perfectly } & \multirow[b]{2}{*}{$8(\%)$} & \multirow[b]{2}{*}{$9(\%)$} & \multirow[b]{2}{*}{$10(\%)$} \\
\hline & $1 \%)$ & $2(\%)$ & & & $5(\%)$ & $6(\%)$ & $7(\%)$ & & & \\
\hline $\begin{array}{l}\text { Sustainability matter to } \\
\text { us as sales marketing }\end{array}$ & $0,70 \%$ & $2,20 \%$ & $1,90 \%$ & $2,40 \%$ & $6,50 \%$ & $7,00 \%$ & $11,80 \%$ & $31,40 \%$ & $30,90 \%$ & $5,30 \%$ \\
\hline $\begin{array}{l}\text { There is a potential } \\
\text { demand for ST products } \\
\text { that must be covered }\end{array}$ & $0,20 \%$ & $1,20 \%$ & $1,00 \%$ & $2,40 \%$ & $3,10 \%$ & $8,60 \%$ & $11,50 \%$ & $34,10 \%$ & $31,90 \%$ & $6,00 \%$ \\
\hline $\begin{array}{l}\text { Tourism can't be } \\
\text { understood without } \\
\text { sustainability in our } \\
\text { destination }\end{array}$ & $0,20 \%$ & $0,50 \%$ & $2,20 \%$ & $2,40 \%$ & $4,60 \%$ & $5,00 \%$ & $10,10 \%$ & $33,30 \%$ & $31,40 \%$ & $10,30 \%$ \\
\hline
\end{tabular}

Source: Authors

When asked about whether they considered that sustainable tourism contributes to boosting the local economy, practically all of the respondents $(96,2 \%)$ agreed with this statement (Figure 1).

Figure 1: ST Contribution to the Local Economy

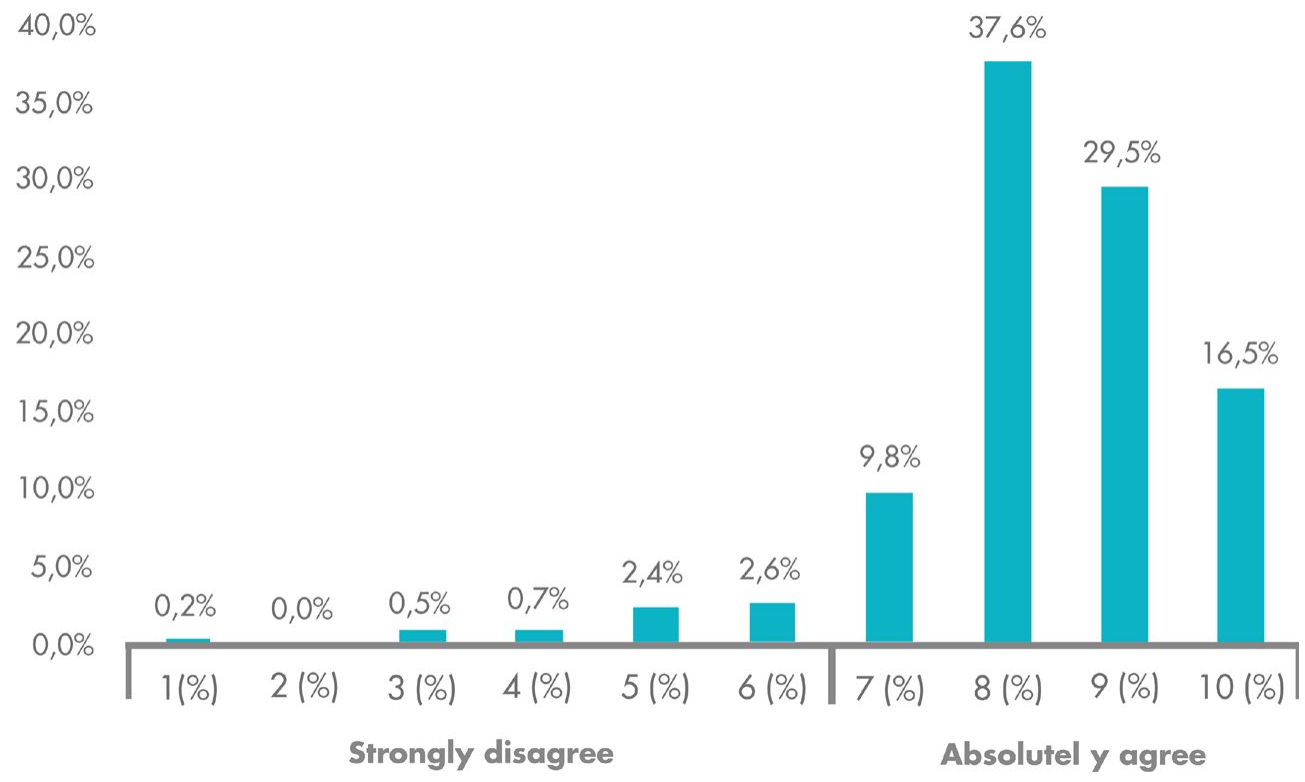

Source: Authors 
Figure 2 shows that the most common strategies of DMOs to increase sustainability upon post-pandemic resumption of tourism include reducing seasonality $(74,3 \%)$, bringing tourism closer to the local community $(68,3 \%)$ and developing practices and behaviours to improve environmental quality $(59,2 \%)$. However, degrowing is not yet in their agenda as a priority.

Figure 2: Common Goals for Sustainable Tourism

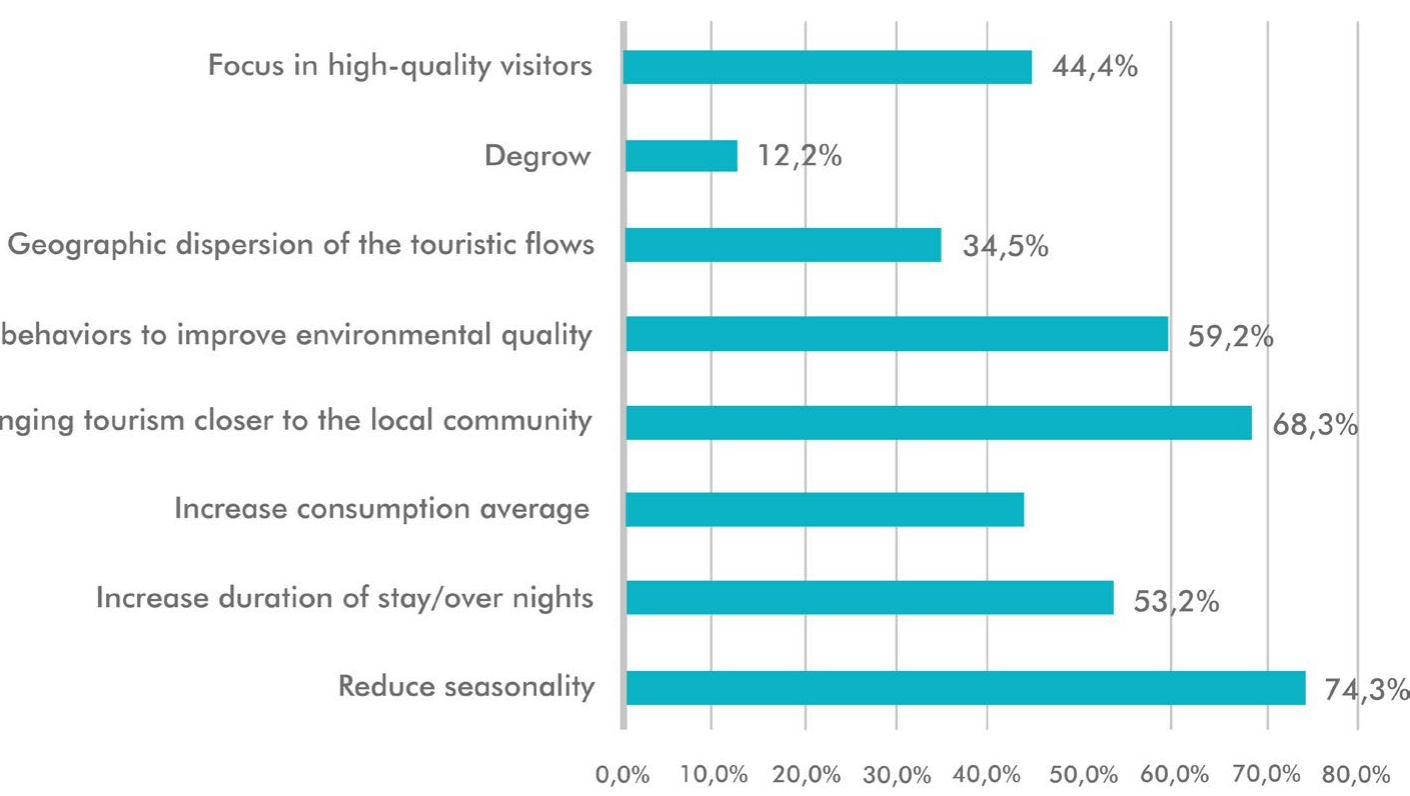

Source: Authors

\section{Discussion}

The general purpose of the study is to verify whether DMOs, in view of the foreseeable increase in the demand for sustainable tourism products upon the post-pandemic resumption of tourism, consider the current situation as a turning point, and whether and how they will become leaders in communicating this type of product.

The primary results obtained show that, even before the crisis began, European DMOs were increasingly focused on tourism sustainability, which was beginning to occupy a privileged position in their strategy. It has been observed that ethical and environmental criteria have become key factors in DMOs marketing decisions as these understand that there is a real and growing demand for this type of product in the market. Accordingly, DMOs deem the current crisis as a turning point in which sustainable tourism is perceived by the market as the one that best meets hygiene and health guarantees (Covid-free) and values such as love of nature and rural life have been reinforced.

As far as sustainable marketing is concerned, it is clear that the crisis communication strategy of DMOs is currently focused on end consumers and not only at an internal organisational level, as discussed above. DMOs 
ensure a greater investment in social media than in other media such as the press, radio or TV. Furthermore, DMOs clearly target those markets where they confirm the existence of a real demand for sustainable tourism products. Upon research it was observed that this type of product is perceived as lost in the usual tourism distribution channels and does not clearly reach the potential end customer, which is one aspect that needs to be addressed.

Therefore, DMOs, from their individual position as one of the main destination stakeholders, should take advantage of the current crisis to promote less standardized and non-mass products in order to reconcile tourism development with the principles of sustainability.

\section{References}

Bakar, N. A., \& Rosbi, S. (2020). Effect of Coronavirus disease (COVID-19) to tourism industry. International Journal of Advanced Engineering Research and Science, 7(4), 189-193.

Blackman, D., \& Ritchie, B. W. (2008). Tourism crisis management and organizational learning: The role of reflection in developing effective DMO crisis strategies. Journal of Travel \& Tourism Marketing, 23(2-4), 45-57.

Buhalis, D., \& Fletcher, J. (1995). Environmental impacts on tourist destinations: an economic analysis. In H. Coccossis \& P. Nijkamp (Eds.), Sustainable tourism development. Avebury.

d'Angella, F., \& de Carlo, M. (2016). Orientation to sustainability and strategic positioning of destinations: an analysis of international tourism websites. Current Issues in Tourism, 19(7), 624-633.

García, A., Soto, L., \& Soutullo, E. (2020). Turismo en tiempos de pandemia: la percepción de los residentes argentinos sobre el riesgo a viajar. Ayana. Revista de Investigación en Turismo, 1(1), 48-55.

Gössling, S., Scott, D., \& Hall, C. M. (2020). Pandemics, tourism and global change: a rapid assessment of COVID-19. Journal of Sustainable Tourism, 29(1), 1-20.

Morgan, N., Hastings, E., \& Pritchard, A. (2012). Developing a new DMO marketing evaluation framework: The case of Visit Wales. Journal of vacation marketing, 18(1), 73-89.

Naumov, N., Ramkissoon, H., \& Hristov, D. (2020). Distributed Leadership in DMOs: A Review of the Literature and Directions for Future Research. Tourism Planning \& Development, 1-17. 
Rivera García, J., \& Pastor Ruiz, R. (2020). ¿̇Hacia un turismo más sostenible tras el covid-19? Percepción de las agencias de viajes españolas. Gran Tour, Revista de investigaciones turísticas, (21), 206-229.

Rivera García, J. \& Pastor Ruiz, R. (in press). DMO (Destination Marketing Organization). In D. Buhalis (Ed.), Encyclopaedia of Tourism Management and Marketing. Edward Elgar Publishing.

Wang, Y. (2011). Destination marketing and management: scope, definition and structures. In Y. Wang, \& A. Pizam (Eds.), Destination marketing and management: Theories and applications (pp.1-20). CABI. 